\title{
TINJAUAN HISTORIS BENTENG VOC DI JEPARA
}

\author{
Agustinus Supriyono \\ Program Magister Ilmu Sejarah, Program Pascasarjana, Universitas Diponegoro, Semarang \\ agust_supriyono@yahoo.com
}

\begin{abstract}
Article entitled "Tinjauan Historis Benteng VOC Di Jepara" (Historical review of the VOC Fortress at Jepara") discussed issues about background and purpose the building of the fortress. Furthermore should be showed the historical evidences which potraied about the VOC Fortress at Jepara. As its result could be conclude that the building of VOC Forttress at Japara has economical, political and military purposes.
\end{abstract}

Keywoords: Jepara, Forttress, VOC, history
ABSTRAK

Artikel yang berjudul "Tinjauan Historis Benteng VOC Di Jepara" membahas permasalahan mengenai latar belakang dan tujuan pembangunan benteng tersebut. Di samping itu akan disajikan bukti-bukti historis yang memberikan gambaran mengenai benteng VOC di Jepara. Dari hasil analisis sumber-sumber yang sejauh ini bisa ditemukan dapat disimpulkan bahwa pembangunan benteng VOC di Jepara mempunyai tujuan yang bersifat ekonomi, politik dan militer.

Kata kunci: Jepara, benteng, VOC, sejarah

\section{PENDAHULUAN}

Benteng VOC di Jepara atau Fort Japara, yang oleh masyarakat setempat lebih dikenal dengan nama Lodji Gunung, terletak di bukit Donorojo, Jepara. Benteng itu dibuat oleh VOC pada pertengahan kedua abad 17, dengan tujuan untuk melindungi aktivitas perdagangan Belanda. Namun demikian pendirian benteng VOC di Jepara itu, yang bahkan kemudian menjadi pusat kekuasaan VOC di Pantai Timur Laut Jawa (Java Noord Oostkust), memiliki kaitan yang erat dengan sejarah kerajaan Demak dan Jepara di bawah pemerintahan Ratu Kalinyamat.

Pada jaman Demak, Jepara merupakan pelabuhan militer kesultanan Demak, dan dari Jepara pula ekspedisi militer laut ke Malaka untuk mengusir Portugis dipersiapkan dan diberangkatkan. Pada jaman pemerintahan Ratu Kalinyamat, pelabuhan Jepara makin berkembang menjadi bandar yang besar yang mempunyai fungsi baik dalam bidang ekonomi dan militer. Meskipun kemudian Jepara dikuasai oleh Mataram Islam, pelabuhan Jepara masih difungsikan sebagai pusat perdagangan terutama untuk ekspor beras oleh kesultanan Mataram, dan juga membawahi daerah-daerah pantai lainnya seperti Jepara, Gresik, Tuban, Rembang, Pati, Kudus, Surabaya, Pasuruan dan sebagainya.

Sampai dasawarsa pertama abad ke 18 Jepara yang dilengkapi dengan benteng yang megah masih merupakan pusat kekuasaan VOC di wilayah pantai Timur Laut Jawa. Namun demikian fungsi benteng semakin menurun sejalan dengan semakin merosotnya aktivitas perdagangan. Sebagai penyebab utamanya adalah dipindahkannya pusat kekuasaan VOC di wilayah Pantai Timur Laut Jawa dari Jepara ke Semarang. 
Sejak saat itu fungsi Jepara dan pelabuhan Jepara sebagai pusat perdagangan semakin merosot. Demikian juga keberadaan Fort Japara menjadi semakin tidak terurus, rusak, meskipun puing-puing bekas kemegahannya masih bisa disaksikan sampai sekarang ini.

Permasalahan utama yang akan dibahas dalam tulisan ini adalah mengenai latar belakang dan tujuan pembangunan benteng VOC di Jepara. Di samping itu juga akan disajikan bukti -bukti sejarah yang berupa gambaran mengenai keberadaan benteng VOC di Jepara.

\section{METODE PENELITIAN}

Sebagai penelitian sejarah, maka metode yang digunakan adalah metode sejarah, yang secara berurutan terdiri dari 4 langkah yaitu sebagai berikut. Pertama, heuristik. Sesuai dengan permasalahan yang diteliti, yaitu sejarah Kerajaan Maritim Jepara abad ke-16, sejarah Mataram di Jepara, dan sejarah VOC di Jepara. Sumber-sumber primer yang bisa diperoleh berasal dari laporan -laporan perjalanan para musafir Portugis dan Belanda, seperti Armando Cortesao, Fernando Mendez Pinto dan De Couto dan lain sebagainya. Khusus mengenai sumber-sumber yang berisi informasi mengenai Benteng VOC di Bukit Donorojo Jepara dapat diperoleh Ensiklopedie van Nederland Indie, dari bukunya Veth, dan dari TBG, tahun 1940, jilid LXXX karya K.C. Crucq, dan dari KITLV Leiden. Untuk sumbersumber sekunder berupa buku-buku penunjang (sejarah, babad, cerita rakyat dan sebagainya), majalah, koran, terbitan berkala dan sebagainya. Yang terakhir yaitu sumber tersier, adalah sumber-sumber yang diperoleh dari hasil wawancara mendalam terhadap orang- orang atau informan yang dianggap mengetahui tentang situs-situs peninggalan Kerajaan Jepara.

Kedua, kritik sumber. Tahap ini merupakan kegiatan untuk mencari informasi-informasi yang bisa dipercaya dari sumber-sumber sejarah, yang dalam Ilmu Sejarah disebut dengan istilah fakta sejarah. Fakta-fakta sejarah masih terpisah secara temporal, spasial, dan substansial, dan baru akan disusun dalam tahap interpretasi atau analisis. Ketiga, Interpretasi atau analisis adalah kegitatan menetapkan makna dan saling hubungan antara fakta-fakta sejarah yang telah diperoleh melalui kritik sumber. Dalam hal ini dari banyak fakta sejarah yang telah diperoleh harus dirangkaikan, disusun atau dihubunghubungkan satu sama lain sehingga menjadi satu kesatuan yang harmonis, menurut rangkaian hubungan yang kronologis dan hubungan sebab akibat. Dari interpretasi ini seharusnya sudah bisa diketahui alur dari kisah sejarah Jepara masa kejayaannya, dan juga gambaran mengenai bentuk benteng Jepara. Langkah selanjutnya tinggal menuangkan hasil interpretasi itu menjadi karya sejarah, yang dalam hal ini laporan penelitian, dan memvisualisasikan gambaran benteng VOC dalam wujud miniaturnya.

Keempat, historiografi atau rekonstruksi sejarah, yaitu kegiatan melakukan sintesa sejarah, atau menyajikan hasil penelitian dalam bentuk kisah sejarah, atau dalam hal ini adalah laporan hasil penelitian. Hasil penulisan, baik gaya bahasa, tata bahasa, panjang pendeknya tulisan, penampilannya adalah sangat tergantung pada siapa yang menulis, yaitu tim peneliti. Tentu saja dalam hal ini tidak akan sama sekali terlepas dari subyektivitas. Di samping laporan penelitian yang berupa kisah sejarah, juga akan dibuat miniatur Benteng VOC, dalam hal ini akan dil- 
akukan melalui kerja sama atau meminta bantuan pakar/ahli dalam membuat miniatur benteng.

\section{HASIL DAN PEMBAHASAN}

\section{Keruntuhan Kota-Kota Maritim di Jawa dan Munculnya Benteng VOC}

Pembangunan benteng-benteng VOC di Nusantara merupakan awal dari kolinialisme Barat khususnya Portugis dan Belanda di Nusantara, sebab dengan benteng-benteng itu Belanda tidak hanya melakukan kegiatan perdagangan, tetapi juga melakukan ekspansi dan intervensi dengan kekuatan militer. Kedatangan bangsa Barat pertama di Nusantara misalnya, dilakukan dengan penaklukan Malaka oleh Portugis pada tahun 1511. Pada waktu itu para pelaut dan pedagang yang bermukim di Malaka terutama terdiri dari suku bangsa Jawa seperti, Jepara, Tuban, Gresik dan para pedagang Timur asing lainnya. Sebagai salah satu reaksi direbut dan dikuasainya Malaka oleh Portugis adalah dilakukannya ekspedisi militer dari kesultanan Demak dan Jepara dengan tujuan untuk mengusir Portugis. Ekspedisi itu pernah dilakukan dua kali, yang pertama di bawah pimpinan Pangeran Sabrang Lor atau juga Pati Unus pada tahun 1512 dan 1513, dan atas perintah Ratu Kalinyamat pada 1551 dan tahun 1574 (de Graaf \& Pigeaud, 1974: 440). Tujuannya tentu saja untuk mengusir Portugis dari Malaka. Reaksi lainnya, yang juga diwarnai oleh alasan sentimen keagamaan, para pedagang dari Jawa, India dan Timur Tengah dan sebagainya menghindar untuk melakukan hubungan dagang dengan orang-orang Portugis yang Kristen. Dalam hal ini mereka mencari kota-kota pelabuhan yang berpenduduk Muslim, antara lain ada yang berpindah ke Aceh, Makasar, Banten, Sunda Kelapa, Brunai, Johor dan kota-kota pelabuhan lainnya di sepanjang pantai utara pulau Jawa. Untuk yang disebut terakhir, jatuhnya Malaka tersebut semakin mendorong berkembangnya beberapa emporium di sepanjang pantai utara Jawa seperti Demak, Jepara, Banten, Cirebon, Surabaya, dan sebagainya. Artinya bahwa kehadiran Portugis sebagai pesaing utama para pedagang Islam di Asia Tenggara secara tidak langsung semakin mendorong militansi dan spirit orang-orang Jawa dalam perdagangan dan pelayaran. Akan tetapi pertumbuhan ekonomi kerajaan-kerajaan pantai di sepanjang pantai utara Jawa itu menimbulkan kecurigaan atau bahkan ancaman bagi Portugis di Malaka.

Pada saat yang sama, kota-kota pelabuhan atau emporium di sepanjang pantai utara Jawa juga terancam oleh munculnya pusat kekuasaan baru di Jawa yang menggantikan Demak yaitu Kasultanan Pajang, setelah meninggalnya Sultan Trenggono pada tahun 1546. Sultan Trenggono wafat ketika sedang memperebutkan kota Pasuruhan. Setelah Trenggono wafat, para pengikut Sultan Trenggono saling bertempur sendiri tidak hanya untuk memperebutkan Pasuruhan, akan tetapi juga Demak, sehingga banyak rakyat yang meninggal dan kapal-kapal perang menjadi hilang. Kemunduran Demak ini berimbas pada Jepara, tetapi dengan melemahnya para pedagang dan pelaut Jawa ini justru membuat Portugis mengambil alih perdagangan orang-orang Jawa di Maluku, dan orang-orang Moor (Islam), di Lautan Hindia.

Pada waktu itu Sultan Pajang memang mempunyai ambisi untuk memperluas wilayah kekuasaannya, terutama ke daerah-daerah atau kota-kota pelabuhan sepanjang pantai utara Jawa. Motivasi utamanya adalah untuk men- 
guasai perdagangan ekspor-impor Jawa dengan daerah-daerah sebarang melalui kota-kota pelabuhan tersebut. Untuk mewujudkan citacita-nya itu, Sultan Pajang mulai melakukan ekspedisi militer atau penyerangan-penyerangan, dengan Kudus dan Demak sebagai korban pertamanya. Baru pada tahun 1599 Jepara dengan susah payah berhasil ditundukkan. Selanjutnya setelah Kesultanan Pajang surut, kerajaan Mataram sebagai penggantinya pada awal abad XVII melanjutkan melakukan ekspansi ke wilayah kota-kota pantai utara Jawa. Khusus untuk kesultanan Cirebon tidak dihancurkan, tetapi secara bertahap didorong oleh Mataram untuk menjadi negara feodal. Kerajaan ini akhirnya tertarik dalam orbit kerajaan Mataram dan berubah menjadi sebuah kerajaan pantai feodal (Sulistiyono, 1994: 135-139). Sebagai akibat ekspansi dan penaklukan-penaklukan itu adalah rusaknya hampir semua sumber ekonomi kerajaan-kerajaan pantai ini, dan terjadinya eksodus para pelaut dan pedagang ke berbagai pelabuhan di Luar Jawa seperti Makassar dan Banjarmasin (De Graaf \& Pigeaud, 1989: 24-29; Burger, 1975, I: 26).

Setelah surutnya Kesultanan Pajang, muncul kasuktanan Mataram di Yogyakarta di bawah pemerintahan raja Sultan Agung (1613-1645). Seperti Sultan Pajang, ia berusaha melanjutkan penaklukan kota-kota pelabuhan di sepanjang pantai utara Jawa. Hasilnya seluruh pelabuhan di pantai utara Jawa Tengah dan Jawa Timur, termasuk Madura, berada dalam wilayah kekuasaan Mataram. Keberhasilan itu memang bisa dimengerti, karena dari segi militer, pemerintahan Sultan Agung dalam sejarah kerajaan Mataram Islam bisa dikatakan yang terkuat di antara rajaraja Mataram sebelumnya. Namun demikian pada masa itu ia harus berhadapan dengan armada laut Belanda
(VOC) yang jauh lebih kuat. Sebagai contoh dalam peperangan menumpas pemberontakan Trunajaya dari Madura armada raja Mataram walaupun jumlahnya banyak yaitu sekitar 1000 perahu, tetapi hanya terdiri dari perahuperahu nelayan yang lebih pantas untuk angkutan penumpang. Sebaliknya Kompeni memiliki armada khusus, yaitu fregat-fregat yang dirancang untuk pertempuran laut. Dengan demikian dari segi kemampuan tempur armada laut Mataram jauh di bawah tandingan armada kompeni (Nagtegaal, 1996: 6869).

Sementara itu, kedatangan Portugis di Nusantara yang telah berhasil menguasai Malaka, disusul dengan kedatangan Belanda dengan VOCnya yang tujuannya tidak lain untuk menguasai dan memonopoli aktivitas perdagangan. Apalagi berbagai komoditi dari Nusantara, khsusnya rempah-rempah, sudah memiliki supply and demand yang relatif mapan baik dalam perdagangan internasional maupun perdagangan antar daerah. Akan tetapi untuk memperoleh dominasinya di Nusantara, baik Belanda maupun Portugis menjalankan sistem perdagangan yang dipersenjatai (armed-trading system) (Pierre-Ives Manguin, dalam Reid (ed.), 1993: 198199). Selanjutnya sistem perdagangan yang dipersanjatai cenderung mendorong terjadinya proses militerisasi akivitas perdagangan di Nusantara. Artinya baik Portugis maupun Belanda menggunakan kekuatan militer untuk mendukung ekspansi perdagangannya. Hal itu bisa dimengerti, apalagi semboyan mereka adalah 'no naval do trading, no fear no friendly', dan Portugis juga mengumumkan 'Perang Salib di lautan'(Chauduri, 1989: 15).

Oleh karena Malaka sudah dikuasai Portugis, Belanda mengalihkan perhatiannya ke Maluku sebagai pusat produsen rempah-rempah. Sesudah 
menguasai Maluku, termasuk Ambon, Belanda bergerak ke Jawa, yang sebagian besar sudah dikuasai oleh Mataram. Dengan cara militer, intervensi dalam konflik intern kerajaan-kerajaan di Jawa dan adu domba (devide et impera) kompeni VOC akhirnya berhasil menguasai kota-kota pelabuhan di sepanjang pantai utara Jawa. Di setiap kota yang berhasil dikuasai, VOC mendirikan benteng untuk melindungi kepentingan bisnis mereka (Ricklefs, 1981: 2746). Selanjutnta kota-kota pelabuhan itu ditempatkan atau diintegrasikan dalam sistem jaringan dagang VOC. Dalam banyak kasus, Belanda berusaha untuk membuat perjanjian-perjanjian yang berfungsi untuk menjamin keuntungan monopoli mereka dalam produksi dan perdagangan (Cowan, 2001: 9). Perjanjian-perjanjian yang mengikat itu merupakan hal baru, menjerat dan tidak lazim di antara para penguasa pribumi di Nusantara.

Setelah berhasil menguasai kotakota pelabuhan di pantai utara Jawa, VOC mulai menaruh perhatiannya ke luar Jawa. Di Banjar atau Banjarmasin yang telah dikenalnya sejak 1596, sementara orang Portugis sebelumnya telah membeli kapur barus, berlian dan batu bezoar, Belanda berusaha mengusai atau memonopoli perdagangan lada. Akan tetapi usaha itu tidak berjalan dengan tanpa hambatan karena para kepala pribumi di sana selalu menolaknya. Baru pada 1635 baru berhasil dibuat kontrak monopoli perdagangan lada.

Setelah beberapa dekade sebelumnya berhasil menancapkan monopolinya atas kepulauan Maluku seperti Ambon dan Ternate pada tahun 1605 dan Banda pada tahun 1609, dan merebut Malaka dari tangan Portugis tahun 1641 (Burger, 75: 28), VOC berusaha untuk menguasai Makasar di Sulawesi, yang bagi Belanda dipandang sebagai musuh yang paling berbahaya di Indo- nesia bagian timur dalam rangka menegakkan monopolinya. Demikianlah setelah melaui perang yang kejam, Belanda berhasil menaklukkan Makasar pada tahun 1667. Pada tahun itu Sultan Hasanuddin menandatangani Perjanjian Bongaya. Setelah penaklukan Makasar bisa dikatakan VOC berhasil menguasai hampir kota-kota pelabuhan atau kerajaan-kerajaan maritim di Nusantara. Selanjutnya dengan politik dagang monopolinya, VOC semakin berjaya di Nusantara. Akan tetapi monopoli itu tidak hanya dikenakan kepada penduduk pribumi, tetapi juga kepada bangsa Eropa yang lain. Dalam perdagangan misalnya, VOC merupakan kekuatan yang memaksa dalam menentukan harga penjualan produk lokal. VOC juga melarang penjualan rempah-rempah kepada orang Eropa lain dengan ancaman hukuman. Dengan cara begitu VOC telah mempermiskin daerah Luar Jawa, menghancurkan perdagangan masyarakat setempat sehingga sulit untuk bisa bangkit kembali (Nagtegaal, 1996: 21). Rempah-rempah dan hasil-hasil hutan dari Luar itu Jawa dikirim ke pelabuhan-pelabuhan di Jawa untuk selanjutnya dikapalkan ke Eropa oleh VOC. Dengan demikian VOC melakukan reformasi jaringan perdagangan di Nusantara, dan disesuaikan dengan jaringan pelayaran global

Salah satu kunci keberhasilan VOC menguasai kerajaan-kerajaan pribumi adalah penggunaan taktik/ politik devide at impera, yang berarti memecah belah dan menguasainya. Taktik ini biasanya lebih sering digunakan untuk memperbesar atau memperparah konflik-konflik intern dalam kerajaankerajaan di Nusantara, terutama konflik -konflik atau perang-perang suksesi. Rentetan tahun-tahun berikut menunjukkan betapa efektifnya penguasaan VOC di Indonesia. 
Tinjauan Historis Benteng VOC ... - Agustinus Supriyono

Tabel 1. Tahapan-Tahapan Penguasaan VOC atas Nusantara

\begin{tabular}{ll}
\hline Tahun & Peristiwa \\
\hline 1596 & $\begin{array}{l}\text { Datang pertama kali di Banten; 1602: mendirikan VOC; 1605: merebut Ambon } \\
\text { dan Tidore dari tangan Portugis }\end{array}$ \\
1609 & Menguasai Banda dan melakukan pelayaran hongi \\
1919 & Merebut Jayakarta (Batavia), \\
1669 & Menaklukkan Makassar \\
1682 & Menaklukkan Banten \\
1705 & Menjadi penguasa di Cirebon, Priangan, Madura, Semarang, Jepara, Rembang, \\
1755 & Surabaya, Ujung Timur \\
\hline
\end{tabular}

Setelah VOC menjadikan Batavia sebagai pusat jaringan perdagangan di Asia Tenggara, Belanda banyak terlibat dalam konflik perebutan tahta di Jawa (Burger, 1975, I: 26-37). Sebagai contoh pengganti Sultan Agung yaitu Sunan Amangkurat I (1645-1677) yang membangun kraton di Plered, tidak jauh dari Karta dan masih termasuk wilayah Yogyakarta, harus menghadapi persekongkolan Kajoran (1662-1667) dengan pemberontak Trunajaya yang mengancam dan membahayakan singgasana Mataram. Berkat bantuan Kompeni VOC, perlawanan Kajoran berhasil dipadamkan, sedangkan Trunajaya berhasil menyelamatkan diri ke Jawa Timur. Sebagai imbalan atas jasa Kompeni tersebut, maka ditandatangani 2 perjanjian yang dipaksakan, yaitu pada bulan Agustus dan September 1646 (George Larson, 1990: 14). Dalam perjanjian itu VOC diijinkan mendirikan loji (kantor dagang) di Semarang, dan menerima hak monopoli perdagangan dari raja (De Graaf, 1996: 172).

Dengan mengeksploitasi konflik internal di kalangan bangsawan, Belanda dapat mengambil keuntungan untuk mengurangi kekuasaan penguasa pribumi sehingga tergantung kepada Belanda. Hingga perempatan terakhir abad XVIII secara bertahap Belanda telah berhasil menempatkan Mataram, Banten, dan dalam derajat tertentu Cirebon berada di bawah 'perlindungan' VOC, setelah sebagian besar wilayah kekuasaannya jatuh ke tangannya. Lebih dari pada itu, dengan menguasai daerah-daerah yang sangat produktif di Jawa, khususnya kota-kota pelabuhan, VOC mendapatkan penghasilan pajak (cukai) pajak dan berbagai penyerahan dari beberapa daerah secara langsung. VOC juga mengintroduksikan tanaman baru yang laku keras di pasaran internasional seperti kopi. Oleh karena sangat manguntungkan, maka VOC cenderung menjadikan Jawa sebagai pusat kekuasaannya dengan memprioritaskan eksploitasi sumber kekayaan dan kesuburan alam Jawa, sementara kekuasaan maritim atas daerah-daerah Luar Jawa (termasuk Malaka) cenderung menurun hingga hancurnya kongsi dagang ini pada tahun 1799 (Cowan, 2001: 10).

\section{Pembangunan Benteng VOC di Jepara}

Benteng Jepara atau dalam bahasa Belanda disebut dengan istilah Fort Japa$r a$, dan yang oleh masyarakat Jepara lebih dikenal dengan sebutan Lodji Gunung, sekarang ini bisa diketahui ter- 


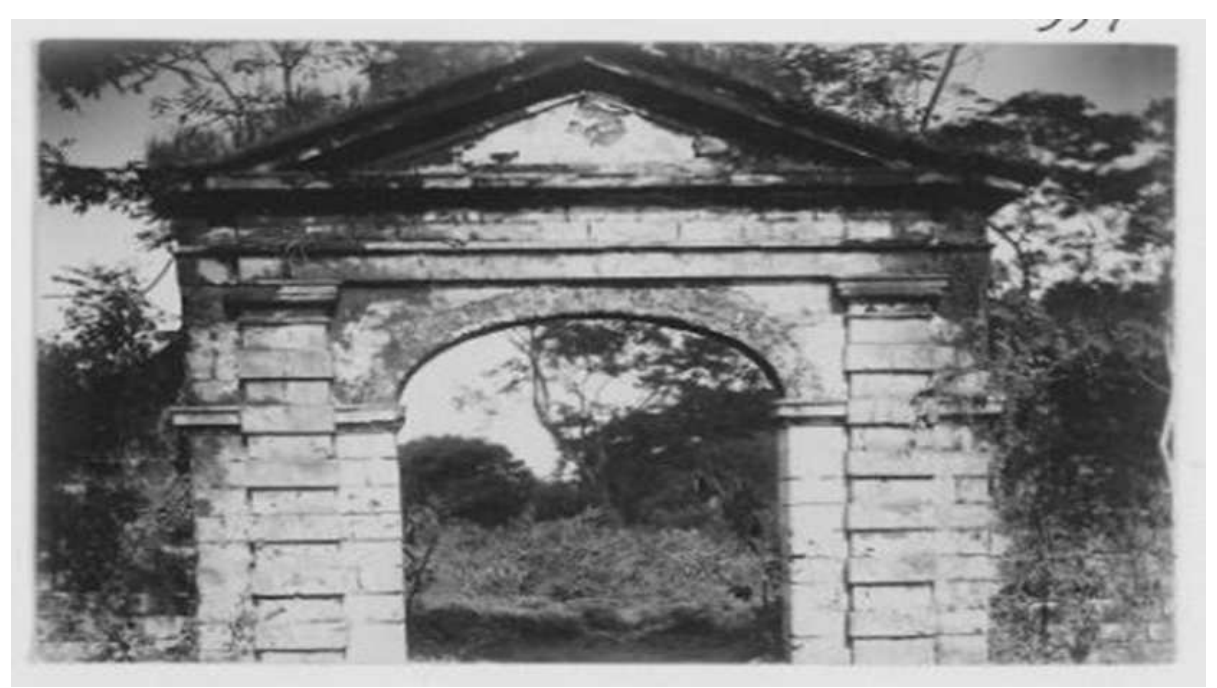

Gambar 1. Gapura Benteng VOC Di Jepara (sumber KITLV)

letak di sebuah bukit sekitar 0,5 km ke arah utara alun-alun Jepara dengan ketinggian 85 meter dari permukaan laut. Pada Gerbang masuk lokasi benteng itu tertera tulisan yang besar yaitu "Fort Japara XVI". Ia merupakan salah satu dari banyak benteng yang dibuat oleh Kompeni Belanda (VOC) dengan tujuan untuk melindungi daerah-daerah atau pelabuhan-pelabuhan yang telah dikuasai terhadap ancaman atau serangan dari laut.

Benteng-benteng yang dibuat sekitar tahun 1680an itu antara lain benteng di Tegal, Semarang, Jepara, Rembang dan Surabaya serta bentengbenteng yang lebih kecil di kota-kota pelabuhan lainnya. Disamping sebagai markas pertahanan dan kantor dagang, benteng-benteng tersebut juga berfungsi sebagai tempat tinggal masyarakat Eropa, yang oleh karena itu juga diberi sebutan sebagai kota-kota benteng (Nagtegaal, 1996: 94). Dengan demikian kemunculan benteng-benteng tersebut sebagai tanda kemunduran kerajaankerajaan maritim di Nusantara, khususnya di sepanjang pantai utara Jawa. Hal itu terjadi sebagai akibat kedatangan bangsa Barat khususnya Belanda, yang kemudian mendominasi dan menguasai kerajaan-kerajaan tersebut.
Seperti telah disebutkan di depan, sebelum kedatangan Belanda di Jawa, yaitu pada masa kejayaan kasultanan Demak (1475-1568), Jepara merupakan bagian dari wilayah kasultanan itu. Oleh karena posisi kota pelabuhan Jepara di sebuah teluk yang lebih aman untuk berlindung kapal-kapal, maka pelabuhan Jepara juga berfungsi sebagai pusat perdagangan dan pelayaran bagi kasultanan Demak. Lebih dari itu pelabuhan Jepara juga merupakan pelabuhan militer dari kasultanan Demak. Posisi dan fungsi pelabuhan Jepara semacam itu tetap bertahan ketika kemudian Jepara berada di bawah pemerintahan Ratu Kalinyamat (15491579). Bahkan pelabuhan Jepara semakin berkembang baik sebagai pelabuhan perdagangan dan militer. Berdasarkan sumber Belanda awal abad XVII dapat diperkirakan bahwa selama menjadi penguasa di Jepara, Ratu Kalinyamat tidak tinggal di istana Kalinyamat (de Graaf dan Pigeaud, 1974: 125), akan tetapi di suatu tempat semacam istana di kota pelabuhan Jepara, dan orang Belanda waktu itu menyebutnya dengan istilah koninghof, yang artinya istana raja (de Graaf \& Pigeaud, 1974: 105). 
Meskipun kerajaan Jepara telah mengalami kemerosotan bukan berarti bahwa pelabuhan Jepara tidak berfungsi lagi, dan peranan Jepara sebagai kota dan pelabuhan perdagangan menjadi sama sekali terhenti. Pelaut Belanda yang pertama kali datang ke Jepara mengambarkan Jepara masih berfungsi sebagai pelabuhan ekspor yang terpenting dari kerajaan Mataram di pedalaman yang semakin besar. Disamping orang-orang Jawa, juga banyak bangsa lain yang berdagang di pelabuhan Jepara antara lain Persia, Arab, melayu, Cina, Aceh, Gujarat, Koramandel, Pegu dan lain sebagainya (Van Wales, 1874, TVNI, II: 428; Lihat juga De Graaf \& Stibbe, 1918: 182).

Pada tahun 1613 oleh Gubernur Jendral VOC yaitu Jan Pieter Both didirikan factorij, atau semacam kantor dagang di Jepara, atas seijin raja Mataram waktu itu yaitu Sultan Agung. Bahkan raja Mataram waktu itu tidak mengajukan persyaratan uang sewa atau cukai jika factorij itu sudah dioperasionalkan. Sementara sebagai alasan pendirian kantor di Jepara karena kantor VOC di Gresik selalu mendapat gangguan dari para pedagang Islam yang tinggal dan berdagang di sana, karena mereka menentang sistem politik dagang monopoli dari VOC (Van Wales, 1874, TVNI, II: 429). Kemudian Pada tahun 1615, VOC diberi izin anggota Raad van Indie (Dewan Hindia) yang bernama Gerard Reynst untuk memperkuat dan mengembangkan factorij itu sehinggga menjadi semacam kota kecil khusus bagi orang-orang Belanda (kompeni) dan sebagai sebagai perwakilan perdagangan VOC di daerah itu (de Graaf, 1974: 56). Sementara pada tahun 1617 factorij itu dikunjugi oleh anggota Raad yang lain yaitu Laurens Reael. Namun demikian pada tahun 1618 factorij itu diserang oleh Mataram, sehingga mengakibatkan tiga orang terbunuh, tiga orang lagi terluka, dan sebanyak 17 orang ditawan. Menurut pihak Belanda penyebab serangan Mataram itu adalah karena perompakan yang dilakukan oleh orang -orang Inggris, sedangkan menurut pihak Inggris disebabkan oleh penolakan Belanda untuk membayar tol atau cukai kepada Mataram. Akan tetapi pihak Mataram menyatakan bahwa penyerangan itu disebabkan adanya hubungan atau skandal asmara antara orang-orang Belanda dengan gadisgadis pribumi di Jepara, yang hal itu dianggap merendahkan kehormatan bangsa pribumi (de Graaf \& Pigeaud, 1974: 165).

Untuk membebaskan tawanan tersebut, maka VOC mengirim pasukan ke Jepara sebanyak 2 kali. Yang pertama pada bulan November 1618 VOC di bawah pimpinan Adriaen Maertensz Block, dan yang kedua pada bulan Mei 1619 di bawah pimpinan J.P. Coen. Dengan dua kali pengiriman pasukan itu kota (factorij) Jepara betul-betul dihancurkan. Namun demikian sumber lain menyebutkan bahwa penyerangan dan pembakaran atas kantor dagang itu juga dilakukan oleh para pelaut dan pedagang Muslim baik yang berasal dari Jepara sendiri maupun dari daerahdaerah atau pulau-pulau yang lain, yang merasa dirugikan oleh kehadiran Belanda VOC dengan lojinya dan sistem monopolinya (De Graaf \& D.G. Stibbe, 1918: 183).

Sumber Belanda lainnya menyebutkan bahwa sesudah dibumihanguskan oleh pasukan kompeni, pada tahun 1621 Mataram meminta kepada kompeni untuk datang lagi ke Jepara, dan mempersilahkan untuk membangun kantor dagang lagi, tetapi permintaan itu ditolak. Akan tetapi ketika kompeni mengirim rombongan utusan ke Mataram pada tahun 1632, mereka justru ditawan oleh Mataram, dan baru 
pada tahun 1647 dibebaskan (de Graaf \& Pigeaud, 1974: 178). Dengan terjadinya peristiwa tersebut hubungan antara Mataram dan kompeni Belanda terputus. Baru pada tahun 1651, ketika Sultan Agung sudah meninggal dan digantikan oleh Amangkurat I, kompeni Belanda mulai lagi membangun tempat kedudukan di Jepara yang dilengkapi dengan comptoir (kantor dagang) dan tidak lama sesudahnya dikembangkan menjadi hoofdcomptoir (kantor dagang besar) (Nagtegaal, 1996: 76). Sebagai pertimbangannya adalah karena pelabuhan Jepara memang memainkan peranan yang penting sebagai pusat jaringan perdagangan dengan daerahdaerah pedalaman, termasuk Mataram, khususnya beras dan kayu yang dijual atau dikirim ke Maluku dan Batavia.

Ketika di kerajaan Mataram terjadi konflik intern di antara bangsawan kerajaan yang kemudian berkembang menjadi pemberontakan, maka raja Mataram meminta bantuan VOC untuk meredamnya. Untuk itu pada tahun 1676 tempat kedudukan VOC di Jepara semakin diperkuat, dan pada tahun 1677 dijadikan markas (legerkamp) tentara kompeni yang bertugas menumpas pemberontakan baik di Jawa Tengah mauun di Jawa Timur. Diperkirakan tahun itu pulalah benteng Jepara yang kuat dibangun. Markas tentara (legerkamp) yang tidak lain benteng Jepara itu terletak pada ketinggian di sebelah timur sungai Jepara dan loji $(\log e)$ di kota yang sudah dilengkapi dengan tanggul rendah (omwalling) dan benteng kecil (bolwerk).

Mengenai pemberontakan yang sulit dipatahkan pada waktu itu adalah yang dipimpin oleh Raden Trunajaya, sehingga terkenal dengan sebutan pemberontakan Trunajaya. Ia sesungguhnya adalah seorang bangsawan Madura yang melakukan pemberontakan terhadap pemerintahan Amangkurat I dan
Amangkurat II dari Mataram. Pasukannya yang bermarkas di Kediri pernah berhasil menyerang dan menguasai serta menjarah isi kraton Mataram tahun 1677. Akan tetapi berkat bantuan pasukan kompeni Trunajaya dapat ditangkap oleh pasukan kompeni di bawah pimpinan Kapitan Jonker pada 27 Desember tahun 1679 (Pigeaud \& de Graff, 1976: 82-84).

Pada tahun 1680an VOC memperoleh konsesi dalam bentuk sewa (gadai) dari raja Mataram atas pelabuhan Jepara (Stapel, 1938-1930: 224). Konsesi itu diberikan oleh Amangkurat II, sebagai imbalan jasa atas bantuan kompeni dalam menumpas pemberontakan Trunajaya. Pelabuhan-pelabuhan lain yang diserahkan oleh Amangkurat II antara lain Tegal, pelabuhan Kaligawe dan Semarang di Semarang, Rembang, Surabaya dan lain-lain. Untuk melindungi daerahdaerah atau pelabuhan-pelabuhan yang sudah dikuasai, khususnya terhadap ancaman serangan dari laut, maka pada tahun 1680an VOC membangun benteng-benteng utama di pantai utara Jawa yaitu di Tegal, Semarang, Jepara, Rembang dan Surabaya serta bentengbenteng yang lebih kecil di kota-kota pelabuhan lainnya. Disamping sebagai kantor tempat pertahanan dan kantor dagang, benteng-benteng tersebut juga berfungsi sebagai tempat tinggal masyarakat Eropa, yang oleh karena itu juga diberi sebutan sebagai kota-kota benteng (Nagtegaal, 1996: 94). Dengan demikian disamping sebagai kantor dagang dan tempat tinggal masyarakat Eropa, benteng-benteng tersebut juga berfungsi sebagai pertahanan terhadap serangan dari laut baik oleh pelautpelaut Nusantara maupun pelaut-pelaut Eropa lainnya.

Khusus untuk kota pelabuhan Jepara di samping dilengkapi dengan benteng yang kuat, juga dijadikan se- 
bagai pusat kekuasaannya di wilayah Pantai Timur Laut Jawa (Noord Oostkust van Java). Pemilihan Jepara sebagai salah satu pusat kekuasaan VOC disamping Batavia pada waktu itu tentu saja atas dasar pertimbangan-petimbangan yang menguntungkan. Pertama-tama, VOC tinggal memanfaatkan sarana dan prasarana pelabuhan Jepara yang sudah ada yang posisinya strategis, dan yang telah dibangun dan dikembangkan pada masa kejayaan Jepara khususnnya pada masa kekuasaan Ratu Kalinyamat. Hal kedua, Jepara pada saat itu masih memiliki daerah-daerah pedalaman yang banyak menghasilkan produk pertanian khususnya beras. Artinya, walaupun dengan pemain yang berbeda, Jepara pada waktu itu masih merupakan kota pelabuhan yang penting.

Berbagai sumber yang sedikit banyak berisi informasi mengenai bentuk fisik benteng Jepara adalah sebagai berikut. Pertama, adalah surat residen Jepara J.P. Metman kepada gubernur Jendral Hindia Belanda pada tanggal 15 Maret 1889, yang salah satu isinya adalah mengenai gambaran singkat mengenai benteng Jepara yang dilampiri dengan peta skesa yang dibuat oleh asisten residen Jepara yang bernama Crane pada tanggal 12 Maret 1889. Meskipun sudah rusak dan hanya berupa puing-puing, kondisi benteng tersebut masih kokoh berdiri. Hanya saja dalam sketsa peta itu tidak dilukiskan bagaimana kira-kira bentuk benteng tersebut. Oleh karenanya manfaat dari sumber ini terbatas sebagai koroborasi (penguat) dan informasi yang kredibel mengenai keberadaan atau lokasi benteng Jepara di kota Jepara.

Kedua, peta benteng Jepara dalam Kota Jepara, termasuk pos-pos VOC yang diperintahkan untuk dibangun oleh Cornelis Speelman pada tahun 1677. Peta itu sesungguhnya merupakan peta kota pelabuhan Jepara, sehingga termasuk di dalamnya dapat diketahui posisi (letak) pos-pos VOC, loji, sungai, pelabuhan dan sebagainya. Dengan demikian peta itu tidak menunjukkan bentuk benteng Jepara, tetapi hanya lokasi benteng tersebut dalam wilayah kota Jepara pada jaman VOC, ketika

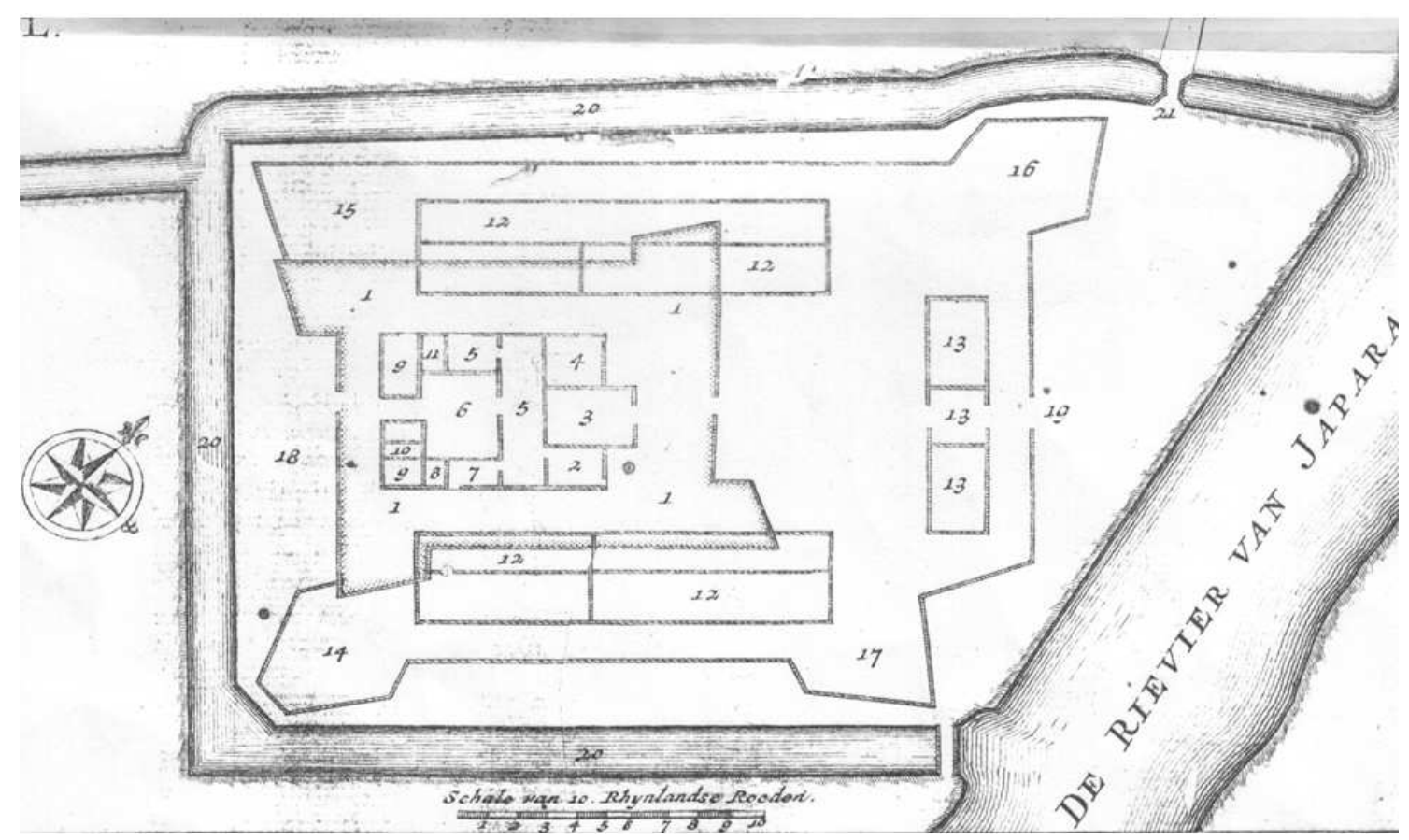

Gambar 2. Denah Loji VOC Di Jepara Dibuat Tahun 1708 Koleksi Arsip Nasional Jakarta 


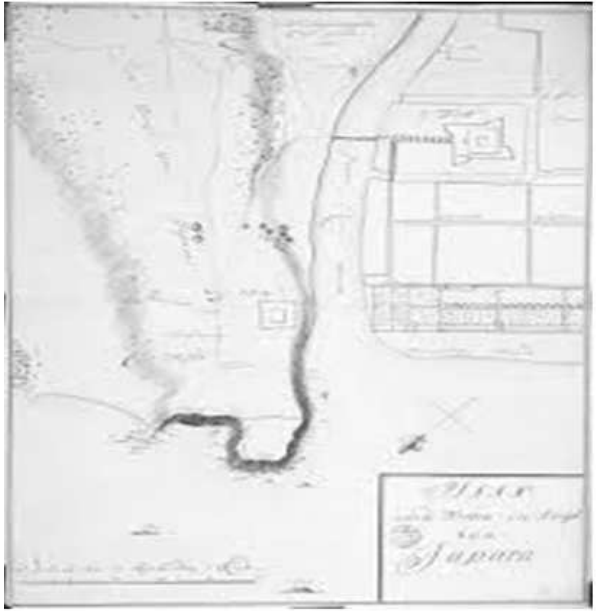

(a)

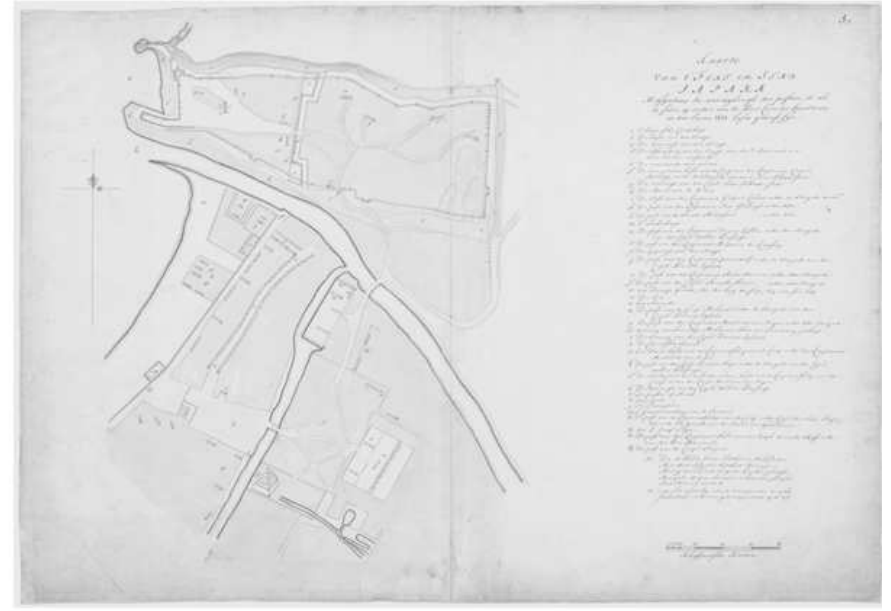

(b)

Keterangan:

(a) Denah Benteng Jepara Tahun 1889 Koleksi KITLV

(b) Denah Benteng Jepara Dalam Kota Jepara Koleksi Arsip Nasional Belanda di Den Haag

Gambar 3. Denah Benteng Jepara Koleksi KITLV dan Arsip Nasional Belanda

Jepara masih menjadi pusat kekuasaan VOC di seluruh wilayah pantai utara bagian timur Jawa (Noord Oostkust van Java)

Ketiga, peta benteng Jepara yang berisi informasi khusus mengenai bentuk datar (peta) benteng tersebut. Dari peta tersebut tentu akan dapat digunakan untuk merekonstruksi bentuk bangun benteng dalam bidang datar, yang kemudian bisa dikombinasikan dengan sumber-sumber yang lain untuk merekonstruksi gabaran tiga demensi benteng Jepara. Untuk lebih jelasnya lihat gambar 4 .

Keempat, lukisan pensil pemandangan kota Jepara dengan latar belakang "Benteng Jepara" Dari gambar tersebut diinformasikan pada sisi timur depan benteng adalah muara sungai Jepara, dan di sebelah bawah kirinya adalah gambar kapal Belanda yang dilengkapi dengan tiga bendera. Agak ke dalam ke arah daratan adalah jembatan yang bisa dibuka dan ditutup (ophaalbrug) dan kandang kuda. Dalam gambar itu letak benteng Jepara adalah pada tepi seberang sungai Jepara. Dengan demikian seperti yang bisa di- saksikan sekarang ini, bahwa letak benteng Jepara adalah pada posisi agak tinggi di atas perbukitan. Meskipun tidak secara detail lukisan tersebut sedikit banyak memberi gambaran mengenai bentuk benteng Jepara.

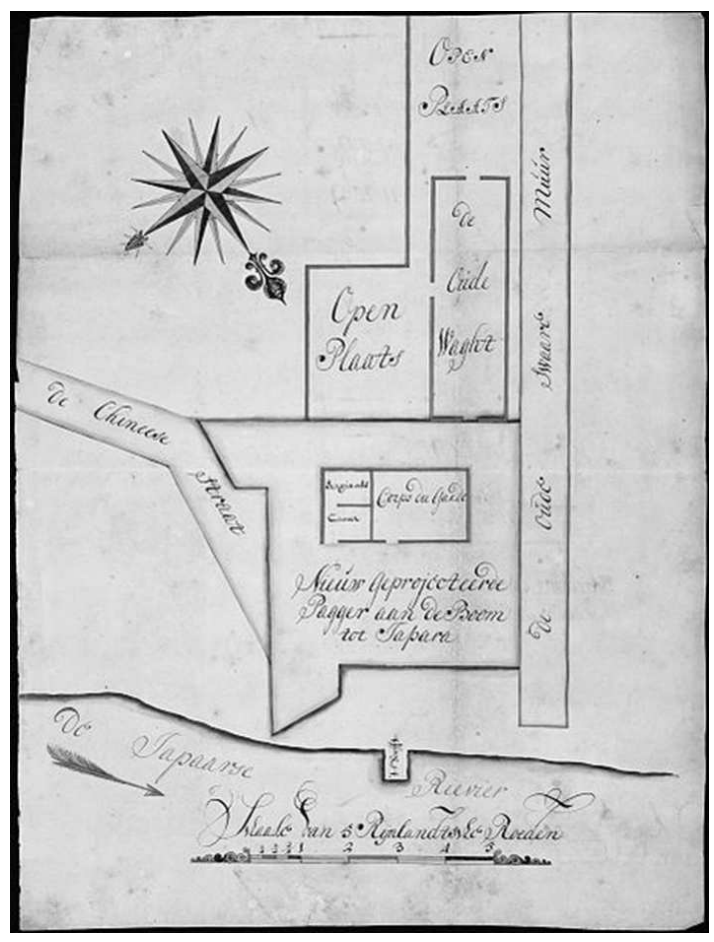

Gambar 4. Peta Benteng Jepara Tahun 1728 Koleksi Arsip Nasional Jakarta 
Tinjauan Historis Benteng VOC ... - Agustinus Supriyono

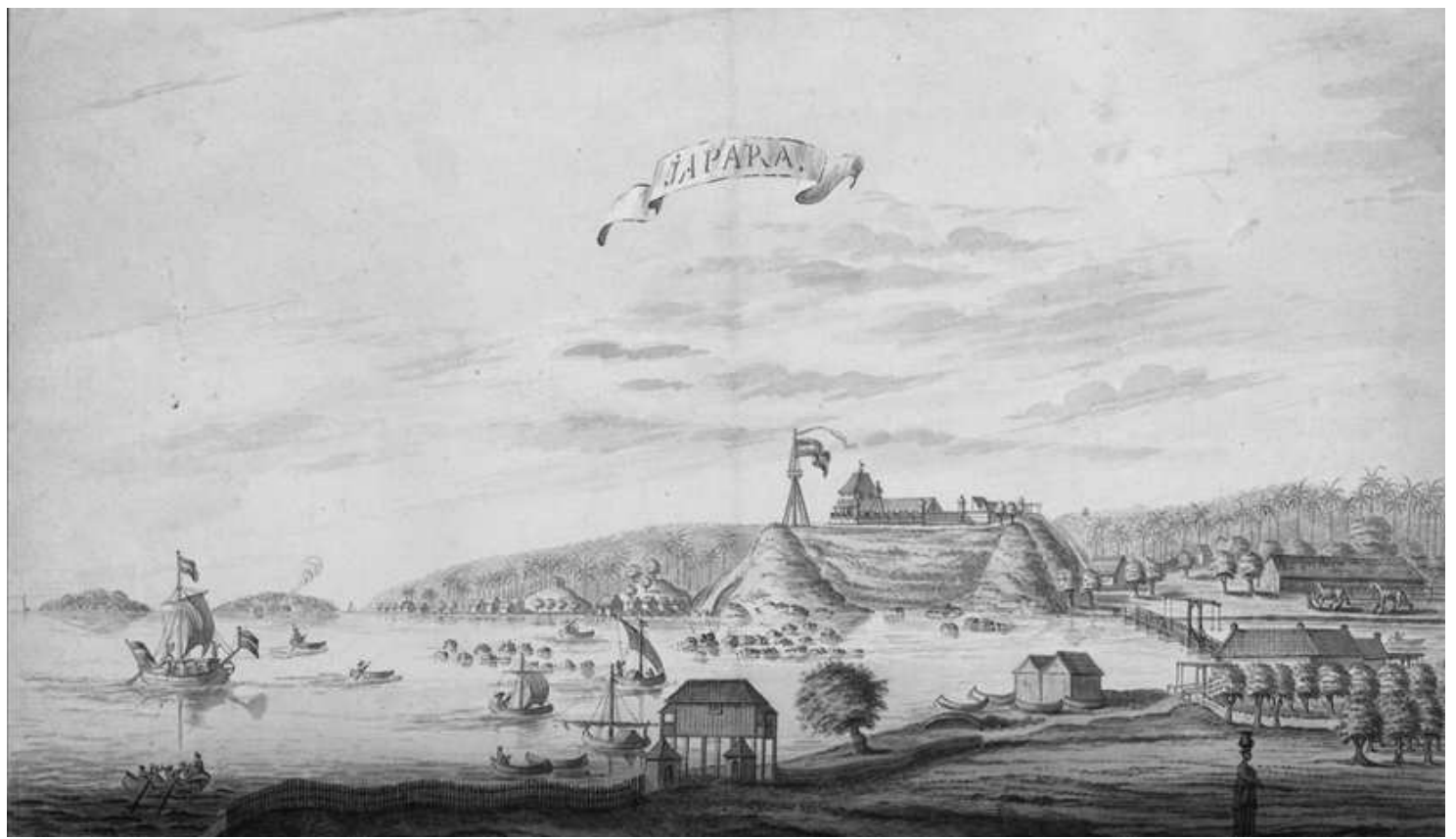

Gambar 5. Lukisan Benteng Jepara dalam Kota Jepara Tahun 1743

Sumber: Koleksi Arsip Nasional Republik Indonesia No. VL 31 \& BG

Versi lain dari gambar pemandangan kota Jepara, termasuk benteng Jepara dengan judul "Gezicht op Japara, richting oosten naar de monding van de Japara rivier, met linksonder een schip met drie Nederlandse vlaggen.- Aan de overzijde van de rivier is een Hollands fort, een beetje landinwaards zijn een ophaalbrug en stallen". Gambar tersebut memberikan informasi yang melengkapi gambar sebelumnya.

\section{SIMPULAN}

Dari seluruh uraian dan pembahasan dalam laporan ini dapat ditarik simpulan sebagai berikut .Pertama bahwa pembangunan benteng-benteng VOC di Nusantara, khususnya di sepanjang pantai utara Jawa merupakan awal dari ekspansi kolinialisme. Ekspansi itu dilakukan dengan berbagai cara, baik secara militer, intervensi maupun politik adu domba (devide et impera). Setelah berhasil menguasai kota-kota atau kerajaan-kerajaan maritim, di samping mendirikan kantor-kantor dagang (comptoir) VOC juga mendirikan benteng-benteng dengan tujuan untuk melindungi kepentingan bisnisnya. Selanjutnya kota-kota pelabuhan itu ditempatkan atau diintegrasikan dalam sistem jaringan dagang VOC di Nusantara.

Salah satu benteng VOC di Jawa adalah benteng di Jepara, yang sengaja dibuat dengan tujuan untuk melindungi kantor dagang di Jepara, dan daerahdaerah atau pelabuhan-pelabuhan yang telah dikuasai terhadap ancaman atau serangan dari laut. Namun demikian terdapat alasan lain yang menyebabkan VOC memilih membangun benteng di Jepara dan bahkan dijadikan sebagai pusat pemerintahan VOC di pantai Timur Laut Jawa (Noord Oostkust van Java). Alasan itu adalah bahwa pelabuhan Jepara merupakan pelabuhan militer pada jaman kerajaan Demak yang semakin dikembangkan ketika Jepara diperintah oleh Ratu Kalinyamat, dan tetap berfungsi ketika Jepara dikuasai oleh kerajaan Mataram Islam. Dengan 
demikian secara fisik kondisi pelabuhan itu masih bagus, sehingga VOC bisa langsung memanfaatkannya. Di samping itu Jepara pada saat itu masih memiliki daerah-daerah pedalaman yang banyak menghasilkan produk pertanian khususnya beras.

Meskipun terdapat pertimbangan ekonomis, pertimbangan politik dan militer juga merupakan alasan penting dibangunnya benteng Jepara oleh VOC. Hal itu berkaitan dengan terjadinya pemberontakan Trunajaya di kerajaan Mataram Islam, dan raja Mataram waktu itu memang meminta bantuan kepada VOC untuk menumpasnya. Untuk menghadapi pemberontakan yang meluas di wilayah Jawa Tengah dan Jawa Timur, pada tahun 1677 VOC melengkapi loji atau kantor dagangnya dengan markas tentara (legercamp), dan yang semakin dikembangkan menjadi benteng. Berdasarkan peta yang terlampir, benteng Jepara itu terletak pada ketinggian di sebelah timur sungai Jepara dan loji $(\log e)$ yang dilengkapi dengan tanggul rendah (omwalling) dan benteng kecil (bolwerk).

Sebagai imbalan jasa atas bantuan kompeni VOC dalam menumpas pemberontakan Trunajaya, maka pada tahun 1680 VOC memperoleh konsesi dari raja Mataram yaitu Amangkurat II dalam bentuk sewa (gadai) dari raja Mataram atas pelabuhan Jepara. Sejak saat itu kota pelabuhan Jepara yang sudah dilengkapi dengan benteng yang kuat dijadikan sebagai pusat kekuasaannya di wilayah Pantai Timur Laut Jawa. Sesudah itu VOC juga membangun benteng-benteng di kota-kota pelabuhan sepanjang pantai utara Jawa. Disamping sebagai kantor dagang, benteng-benteng tersebut juga berfungsi sebagai pertahanan terhadap serangan dari laut baik oleh pelaut-pelaut Nusantara maupun pelaut-pelaut Eropa lainnya, dan sebagai tempat tinggal masyarakat Ero- pa. Demikianlah, seperti telah disebutkan di depan, di kota-kota pelabuhan dimana didirikan benteng VOC disebut dengan istilah sebagai kota-kota benteng.

\section{DAFTAR PUSTAKA}

Burger, D.H. 1975. Sociologisch-Economische Geschiedenis van Indonesia I. Amsterdam: Royal Tropical Institute.

Chauduri, K.N. 1989. Trade and Civilization in Indian Ocean: An Economic History from the Rise of Islam to 1750. Cambridge: Cambridge University Press.

Cowan, C.D,. 2001. Continuity and change in the international history of maritime South East Asia, 9, 2001.

Gaastra, F.S., 2002, De geschiedenis van de VOC, Zutphen: Walburg.

Gaastra F.S. \& J.R. Bruijn, 1993, 'The Dutch East India Company's Shipping, 16021795, in a comparative perspective', dalam: J.R. Bruijn \& F.S. Gaastra (eds), Ships, Sailors and Spices: East India Companies and their Shipping in the $16^{\text {th }}$, 17th and $18^{\text {th }}$ Centuries, Amsterdam: NEHA.

Graaf, De \& D.G. Stibbe1918. Encyclopedie van Nederlandsch-Indië.t weede deel. 'S Gravenhage: Martinus Nijhof.

Graaf, H.J. de \& Th. G. Th. Pigeaud. 1974. De Eerste Moeslimse Vorstendommen op Java. 's Gravenhage: Martinus Nijhoff

Graaf H.J de,. \& Th. Pigeaud. 1989. Kerajaan -kerajaan Islam di Indonesia. Jakarta: Grafiti Press.

Graaf H.J de. 1986. Puncak Kekuasaan Mataram. Politik Ekspansi Sultan Agung. Jakarta: Pustaka Utama Grafiti.

Larson, George. 1990. Masa Menjelang Revolusi, Kraton dan Kehidupan Politik di Surakarta 1912-1942. Yogyakarta: Gadjahmada University Press.

Manguin, Pierre-Ives. 1993. “The Vanishing Jong: Insular Southeast Asian Fleet in Trade and War (Fifteenth to Seventeenth Centuries)". Dalam A. Reid (ed.). Southeast Asia in the Early Modern Era: Trade, Power, and Belief. IthacaLondon: Cornell University Press, 
Tinjauan Historis Benteng VOC ... - Agustinus Supriyono

1993.

Nagtegaal, L. 1996. Riding the Dutch Tiger: The Dutch East Indies Company and the Northeast Coast of Java 1680-1743. Leiden: KITLV Press

Ricklefs, M.C. 1981. A history of Modern Indonesia c. 1300 to the Present. London: Macmillan.

Stapel, F.W. 1938-1940, Geschiedenis van Nederlandsch-Indië, 5 dln. Amsterdam: Joost van den Vondel.

Siddique, S. 1977. "Relics of the Past? A Sociological Study of the Sultanates of
Cirebon, West Java". Dissertation, University of Bieleveld.

Sulistiyono, S.T. 1994. "Perkembangan Pelabuhan Cirebon dan Pengaruhnya terhadap Kehidupan Sosial Ekonomi Masyarakat Kota Cirebon 1859-1930". Tesis. Universitas Gadjah Mada, Yogyakarta.

Thian Joe, Liem. 1951. Riwayat Semarang. Semarang, Batavia: Boekhandel Ho Kim Yoe

Van Wales. 1874. "Jepara", Tijdschrift voor Nederlandsch Indië (T.V.N.I,) II. 